\title{
INKLUZYWISTYCZNA REINTERPRETACJA POJĘCIA WIARY U PAULA TILLICHA I JEJ IMPLIKACJE DLA PRAKTYKI EDUKACJI RELIGIJNEJ
}

\begin{abstract}
Streszczenie: Tillich reinterpretuje chrześcijańskie pojęcie wiary w Boga jako bytu i ukazuje je jako troskę ostateczną. Wiara staje się więc centralnym i koniecznym stanem wszystkich. Chociaż podmiot wiary jest skończony, to ma zdolność do dążenia do ostatecznego, nieskończonego przedmiotu. Przedmiot wiary może być wyrażony jedynie symbolicznie, zatem nie istnieje jeden prawdziwy symbol wiary. Skończona natura przedmiotu w sposób nieunikniony rodzi zwątpienie i błądzenie. Takie ujęcie wiary ma implikacje dla edukacji religijnej. Ta winna stać się inkluzywną, włączającą wszystkich ludzi, zarówno religijnych, jak i niereligijnych, pomagać im pogłębiać ich wiarę, zgodnie z poszczególnym jej rozumieniem, a także przestrzegać przed niebezpieczeństwem absolutyzacji poszczególnych symboli wiary. Szczególnie teistyczne religie winny pamiętać o tym, że ostateczny obiekt wiary wykracza poza absolutny byt. Troska ostateczna, chociaż niebezpośrednio, to jednak jest także obecna w świeckim, nie tylko religijnym doświadczeniu.
\end{abstract}

Słowa kluczowe: Tillich; troska ostateczna; wiara; edukacja religijna; inkluzywizm.

Paul Johannes Tillich (1886-1965) to jeden $\mathrm{z}$ najwybitniejszych myślicieli luterańskich XX wieku. W 1910 roku uzyskał stopień doktora filozofii Śląskiego Uniwersytetu im. Fryderyka Wilhelma we Wrocławiu (Matuszyk 2015, s. 29). Jeden z istotnych wątków refleksji teologiczno-filozoficznej Tillicha dotyczył pojęcia wiary chrześcijańskiej. W 1956 roku Tillich wydał książkę pt. Dynamika wiary (korzystam z Tillich 1987). Jako postępowy teolog, Tillich akceptował wiele z ówczesnej krytyki kierowanej przeciwko religii chrześcijańskiej. Między innymi odrzucił tradycyjnie rozumianą wiarę jako zaufanie istocie boskiej, która w cudowny sposób ingeruje w świat i pomaga tym, którzy w nią wierzą. Odrzucenie przez Tillicha tradycyjnego rozumienia Boga i jego działania automatycznie zmusiło go do reinterpretacji samego pojęcia wiary (por. rozdz. 3: Wiara i edukacja. Analiza teologiczna. W: Milerski 1998a, przybliżający egzystencjalne rozumienie wiary i jej implikacje dla ewangelickiej pedagogiki religijnej). 
Według Tillicha, właściwe rozumienie wiary nie zależy od tego, czy ktoś uznaje istnienie Boga jako odrębny byt, czy też go odrzuca. Tillich rozumie wiarę jako coś właściwego każdemu człowiekowi, bez względu na jego przekonania religijne. Z tego też względu Tilllichowska reinterpretacja wiary jest inkluzywistyczna w swej naturze. Niniejsza praca stawia sobie za cel przybliżenie podstawowego zarysu Tillichowskiej koncepcji wiary z jednoczesnym wskazaniem na jej możliwości wykorzystania w praktyce edukacji religijnej.

\section{Odrzucenie pojęcia wiary}

Tillich rozpoczyna książkę Dynamika wiary od następującego zdania: „Chyba żadne inne słowo należące do języka religijnego zarówno teologicznego, jak i potocznego - nie prowadzi do tylu nieporozumień, zniekształceń i budzących wątpliwości definicji co słowo "wiara»" (Tillich 1987, s. 30). Według niego tradycyjnie rozumiana wiara powoduje różne błędne postawy, od sceptycyzmu, aż po fanatyzm. Obie te niewłaściwe i skrajne reakcje wypaczają właściwe rozumienie religii.

Z tegoż to powodu Tillich kontynuuje: „Odczuwa się wręcz pokusę, by zaproponować całkowita rezygnację z terminu «wiara», co może i byłoby pożądane, ale jest prawie niemożliwe" (Tillich 1987, s. 30). Jest to zaskakujące stwierdzenie. Luterański teolog zastanawia się nad całkowitym zarzuceniem podstawowego pojęcia w teologii protestanckiej, jakim jest wiara, i to w imię obrony jej znaczenia. Wie jednak, że nie jest to możliwe, dlatego też podejmuje się reinterpretacji pojęcia wiary. Żywi nadzieję, że jego propozycja pomoże odkryć „ukrytą moc wiary” (Tillich 1987, s. 30) u swoich czytelników - i to bez względu na ich osobiste przekonania religijne.

\section{Definicja wiary}

Tillich definiuje wiarę jako „stan najwyższego zatroskania”, jako „troskę ostateczną” (Tillich 1987, s. 30). Podobnie jak inne żywe istoty, człowiek troszczy się o to, co będzie jadł i gdzie będzie mieszkał. Dodatkowo, jako istota duchowa, troszczy się o rzeczy dotykające sfery intelektualnej, estetycznej, społecznej, politycznej, religijnej i innej. Ostatecznie któraś z tych sfer zaczyna dominować i staje się tak istotna, że wymaga od niego całkowitego poświęcenia. Przykładem takiej troski ostatecznej może być troska o naród czy też sukces zawodowy, która podporządkowuje sobie i nieraz zaniedbuje inne troski (o rodzinę, o dobrobyt, o prawdę) (Tillich 1987, s. 31). Innymi słowy, według Tillicha, wiara dotyczy tego, co nas ostatecznie obchodzi i czemu jesteśmy w stanie poświęcić wszystko. Każdy człowiek czemuś się oddaje, coś nadaje sens jego życiu (Mech 1999, s. 257-260). Każdy przejawia troskę o coś, czemu ufa. Zatem każdy wierzy, bo ufa, że to, czemu się poświęcił, obdarzy go zaspokojeniem i szczęściem. 


\section{Wiara jako centralny akt}

Tillich twierdzi, że człowiek może ufać i wierzyć czemuś zgodnie ze swoim rozumem, ale też równie dobrze działać przeciw niemu, zatem wiara przekracza sferę racjonalną u człowieka. Podobnie jest ze sferą emocjonalną i wolicjonalną. Wierzyć można wbrew emocjom i woli, jak również zgodnie z nimi. Wiara zatem przekracza wszystkie „składowe” osoby człowieka, przez co staje się jego centralnym aktem, wypadkową myślenia i działania.

\section{Ostateczny charakter podmiotu wiary}

Człowiek jest istotą skończoną, niedoskonałą. Nie wie wszystkiego, nie umie wszystkiemu sprostać, nie potrafi kochać w sposób pełny. Wszystko to, co myśli, czuje, chce, robi, ma charakter czasowy, niedoskonały. Posiada jednakże zdolność do abstrakcyjnego myślenia, do myślenia w kategoriach nieskończoności, wieczności, nieprzemijalności, doskonałości. Zatem pomimo tego, że jest ograniczony, to potrafi myśleć o rzeczach nieograniczonych. Skoro człowiek potrafi myśleć o doskonałości, to oznacza, że wiara - jako wypadkowa jego myślenia i działania - musi być w swej naturze także nieograniczona. Skoro człowiek potrafi myśleć o rzeczach ostatecznych, to także i jego wiara winna być podobnej natury.

Innymi słowy, każdy człowiek - świadomie lub nie - w jakiś sposób kształtuje swoje życie. Są rzeczy, którym poświęca trochę czasu, ale są i sprawy, którym oddaje się bez reszty. To właśnie oddanie Tillich nazywa wiarą - troską przewyższającą wszystkie inne troski i podporządkowującą je sobie. Skoro człowiek potrafi myśleć o rzeczach ostatecznych, to także $\mathrm{w}$ akcie wiary będzie musiał się ostatecznie czemuś oddać, bez względu na to, czy tego chce czy nie.

\section{Ostateczny charakter przedmiotu wiary}

Skoro człowiek potrafi myśleć o nieskończoności, to automatycznie oznacza, że przedmiot jego troski także winien być nieskończony (Tillich 1987, s. 37). Zatem zarówno subiektywny element wiary („to, mocą czego się wierzy”), jak i obiektywny element wiary („to, w co się wierzy”) muszą być ostateczne (Tillich 1987, s. 38). Nieuwarunkowana niczym troska, a więc wiara wykraczająca poza wszelkie doczesności i zmienności, automatycznie się domaga, aby jej przedmiotem było coś, co także jest nieuwarunkowane (Tillich 1987, s. 37). Oznacza to, że istnieje związek między wiarą a jej przedmiotem. Przedmiot wiary - podobnie jak i jej podmiot także musi być „nieuwarunkowany” oraz „ostateczny” (Tillich 1987, s. 37). 


\section{Właściwy przedmiot wiary}

Zatem chociaż wspomniana wcześniej troska o naród czy troska o sukces życiowy nieraz roszczą sobie prawo do bycia ostatecznymi przedmiotami wiary człowieka, to jednak jest to fałszywa ostateczność. Są to bowiem troski o rzeczy zmienne, uwarunkowane, a więc w swej istocie nieostateczne, nieprzystające do ostatecznego charakteru aktu wiary. Tillich (19878, s. 39) pisze: „Prawdziwa wiara czyni obiektem swej ostatecznej troski to, co naprawdę jest ostateczne, podczas gdy wiara bałwochwalcza podnosi do rangi rzeczy ostatecznych rzeczywistości doczesne, skończone. Niemożliwą do uniknięcia konsekwencją wiary bałwochwalczej jest «egzystencjalne rozczarowanie»". Na jakiś czas przedmiot wiary może pozostawać nieostateczny. Ostatecznie jednakże musi on zbudzić rozczarowanie, gdyż otwarty na nieskończoność człowiek nie może zostać usatysfakcjonowany skończonością (Tillich 1987, s. 39). Takie ujęcie podmiotu, jak i przedmiotu wiary ma charakter inkluzywistyczny. Niesie przesłanie dla każdego człowieka, który - oczekując czegoś nieuwarunkowanego i jednocześnie oddając się czemuś uwarunkowanemu narażony jest na rozczarowanie i kryzys.

\section{Bóg jako przedmiot wiary}

Tillich przekonuje, że skoro właściwym przedmiotem wiary ma być to, co ostateczne i nieskończone, to opis tego czegoś będzie musiał być z definicji symboliczny, wykraczający poza realność świata, który jest w swej naturze skończony. Wszelka dosłowność będzie nawiązywać bezpośrednio do elementów rzeczywistości człowieka, a przez to nie jest w stanie wyrazić nieskończonego przedmiotu wiary (Tillich 1987, s. 64).

To, że człowiek, ze względu na podmiot swej wiary, jest zmuszony wyrazić przedmiot swej wiary językiem symbolicznym, a nie dosłownym, nie oznacza, że coś traci (Tillich 1987, s. 65). Język symboliczny jest bogatszy od dosłownego. Ukazuje nam te sfery rzeczywistości, których język dosłowny nie rozświetla. „Obraz lub wiersz odsłaniają elementy rzeczywistości, do których nie można się zbliżyć na sposób naukowy" (Tillich 1987, s. 63). Jeśli człowiek chce pozbyć się języka symbolicznego - bez względu na to, czego on dotyczy - na rzecz języka naukowego, to z pewnością straci w głębi swej egzystencji, której nie da się wyrazić językiem technicznym (Tillich 1987, s. 69). Oznacza to, że Bóg jako przedmiot wiary chrześcijańskiej nie będzie i nie może być rozumiany dosłownie. Nazwać Boga np. „wszechmocnym”, oznacza skorzystać z ziemskiego, ludzkiego doświadczenia mocy i wyrazić ją w sposób nieskończony (Tillich 1987, s. 67); powiedzieć, że Bóg „istnieje”, to znaczy także wyrazić się językiem symbolicznym, gdyż tylko ziemskie przedmioty czy byty dosłownie istnieją (Tillich 1987, s. 66).

Tillich jako chrześcijanin powie, że rzeczywiście przedmiotem wiary człowieka jest Bóg. Trzeba jednak dobrze zrozumieć to, co on przez to ma na myśli. Skoro 
Tillich zredefiniował pojęcie wiary, musiał również zredefiniować pojęcie Boga. Dla Tillicha Bóg jako taki nie jest osobą (Mech 1997, s. 138), lecz - jak nadmienimy też jeszcze poniżej - jest Samym Byciem (Tillich 2017, s. 97). Tillich w innym kontekście powie: „Bóg, będący bytem, jest transcendowany przez Boga, będącego Samym Byciem, podstawą i bezmiarem wszelkiego bytu. A Bóg, będący osobą, jest transcendowany przez Boga, będącego samym Byciem Osobą, podstawą i bezmiarem wszelkiego bycia osobą" (Tillich 1994, s. 130).

Jeśli powiemy w tradycyjnym znaczeniu, że przedmiotem wiary ma być Bóg, to automatycznie nie zgodzą się z tym ateiści. Tillich jednakże powie, że nawet jeśli ktoś neguje istnienie Boga, to i tak przedmiotem jego wiary pozostaje bóg (przez małe 'b’), ale bóg rozumiany jako nieskończona, ostateczna rzeczywistość, której się bezwarunkowo oddajemy, czy jest nią przywoływany już sukces zawodowy czy jeszcze coś innego.

Tillich utrzymuje, że ateista, negując istnienie Boga, jednocześnie potwierdza, że istnieje coś takiego jak pytanie o to, co ostateczne, a więc istnieje pytanie o Boga jako takiego. Nie musi to być teoretycznie Bóg chrześcijański. Istnieje wiele innych konkretnych wyobrażeń tego, co ostateczne (Tillich 1987, s. 66). Na przykład w przypadku biblijnego Izraela konkretnym wyobrażeniem Boga będzie Jahwe, zaś w humanistycznym typie wiary idea człowieka.

\section{Wiara a ateizm}

Inkluzywistyczna reinterpretacja pojęcia wiary skutkuje więc nie tylko reinterpretacją pojęcia Boga jako tego, co ostateczne, lecz także reinterpretacją ateizmu: „Ateizm może [...] oznaczać jedynie usiłowanie usunięcia wszelkiej troski ostatecznej - trwanie w stanie beztroski o sens własnej egzystencji. Obojętność względem ostatecznego pytania jest jedyną wyobrażalną postacią ateizmu. Czy jest ona możliwa, to problem, który musi pozostać na razie nierozstrzygnięty (por. kontynuację tego wątku u Tillicha [1987, s. 111], który puentuje następująco: „Dlatego też nie można twierdzić, iż istnieją ludzie pozbawieni jakiegoś rodzaju troski ostatecznej, czyli ludzie pozbawieni wiary"). Tak czy inaczej, ktokolwiek neguje Boga jako sprawę ostatecznej troski, Boga afirmuje, gdyż w jego trosce wyraża się afirmacja ostateczności" (Tillich 1987, s. 65).

Dla przykładu, Tillich uważa, że negacja przez człowieka istnienia i działania istot boskich nie oznacza, że ten okazuje się być bez wiary (Tillich 1987, s. 78). Tillich (1987, s. 79) pisze: „Ludzi mówią często, że są świeckimi, że żyją poza wrotami świątyni, a zatem że pozbawieni są wiary! Jeśli jednak zapytać ich, czy nie przejawiają jakiejś ostatecznej troski, czy pozbawieni są czegoś, co uważają za bezwarunkowo ważne, stanowczo temu zaprzeczą. Zaprzeczając zaś, jakoby pozbawieni byli pewnej troski ostatecznej, potwierdzają, iż znajdują się w stanie wiary. Reprezentują oni humanistyczny typ wiary posiadający wiele odmian; to, że uważają się za świeckich, nie wyklucza ich ze wspólnoty wyznawców". 


\section{Uniwersalny symbol przedmiotu wiary}

Zadanie więc ostatecznie polega na dyskusji o tym, które $\mathrm{z}$ dostępnych symboli przedmiotu wiary będzie najtrafniej oddawać jego ostateczność. Dla przykładu, jeśli ktoś za przedmiot swojej wiary bierze dane drzewo, naród, to automatycznie zrodzi się pytanie o to, czy te symbole rzeczywiście pomagają mu najtrafniej wskazywać na to, co ostateczne.

Czy istnieje jakiś jeden uniwersalny symbol przedmiotu wiary? Tillich odpowiada: „Możliwe, że wiara [...] nigdy nie zdoła wyrazić się w jakimś jednym konkretnym symbolu, choć każda wielka religia żywi nadzieję, że właśnie ona dostarczy owego uniwersalnego symbolu, w którym znajdzie wyraz wiara wszystkich ludzi. Nadzieja taka jest uprawniona, jeżeli żywiąca ją religia świadoma jest warunkowego i nieostatecznego charakteru własnych symboli" (Tillich 1987, s. 126; por. Patalon 2007, s. 167-168).

\section{Niedoskonałość podmiotu wiary}

„Serce człowieka poszukuje tego, co nieskończone. W tym, co nieskończone, upatruje ono własnego spełnienia” (Tillich 1987, s. 40). Z drugiej zaś strony „człowiek uświadamia sobie zarazem nieskończony dystans dzielący to, co skończone, od tego, co nieskończone" (Tillich 1987, s. 40). Innymi słowy, człowiek wie, że nigdy jako skończony byt nie złączy się w pełni z tym, co nieskończone. Ponieważ człowiek w swej skończoności wierzy w coś, co jest nieskończone, to automatycznie jego wiara nie będzie doskonała, pozostanie pełna niepewności. „Owego elementu niepewności nie da się z wiary usunąć, trzeba go zaakceptować” - twierdzi Tillich (1987, s. 42). Nawet jeśli przedmiotem wiary będzie to, co nieskończone, jakkolwiek symbolicznie wyrażone, to i tak wierzący człowiek przez swą skończoność będzie doświadczał zwątpienia. Nie ma więc wiary bez wątpienia. Zawsze pozostaje ryzyko, że to, co uznajemy za ostateczne, i to, czemu oddajemy się ostatecznie, może okazać się nieostateczne.

\section{Nieomylność Kościoła}

Z wątpieniem związane jest także pytanie o autorytet Kościoła i nieomylność jego orzeczeń. Tillich, zakładając wątpienie jako integralną część wiary, dochodzi do przekonania o niemożliwości istnienia „nieomylności”. „Nieomylność” podważa przekonanie o możliwości wątpienia człowieka. Żadna „ludzka interpretacja treści wiary od autorów biblijnych po współczesnych" (Tillich 1987, s. 51) nie może być ostateczna, a to dlatego, że skończony ludzki byt interpretuje to, co nieskończone.

„Jakiekolwiek - liturgiczne, doktrynalne bądź etyczne - sposoby wyrazu wiary wspólnoty nie mają charakteru ostatecznego. Ich funkcja polega raczej na wskazywaniu tego, co ostateczne, a co wykracza poza nie wszystkie. To właśnie nazywam 
„Zasadą protestantyzmu” - pisze Tillich (1987, s. 52) - owym elementem krytycznym występującym w formach wyrazu wspólnoty wiary, w konsekwencji zaś elementem wątpienia zawartym w akcie wiary". Wskazanie na wątpienie i nieostateczny charakter dogmatu Tillich opisuje jako jedno z dokonań protestantyzmu wobec katolicyzmu.

\section{Wiara a edukacja religijna - możliwe implikacje}

W powyższym przybliżeniu reinterpretacji pojęcia wiary ograniczono przedstawienie tego, jak pozytywnie Tillich reinterpretuje religię chrześcijańską, którą reprezentuje. Celem bowiem było ukazanie inkluzywistycznego charakteru wiary, przejawiającego się w jej osobowej centralności, jako aktu, konieczności jej artykulacji oraz ostateczności jej podmiotu i przedmiotu. Takie ujęcie wiary przekracza ekskluzywizm wyznaniowy zbiorowości religijnej bądź innej. Główne punkty powyższego wywodu można sprowadzić do następujących czterech zagadnień: (1) centralność i konieczność wiary; (2) ostateczność podmiotu i przedmiotu wiary; (3) symboliczność i różnorodność wiary; (4) niedoskonałość podmiotu wiary oraz nieuchronność zwątpienia i błądzenia. Można teraz poddać je refleksji z perspektywy edukacji religijnej:

1. Przekonanie Tillicha o tym, że wiara przekracza racjonalność, wolicjonalność i emocjonalność człowieka oraz stanowi wypadkową jego funkcjonowania jako podmiotu prowadzi do wniosku o uniwersalnej obecności wiary w życiu każdego człowieka. Uniwersalność doświadczenia ostatecznego zatroskania, a więc posiadania wiary, w tym także u osób o świeckich przekonaniach, skutkuje wnioskiem o możliwości przeformułowania praktyki edukacji religijnej. W tym świetle może być ona realizowana inkluzywistycznie, przekraczać i obejmować swym zakresem poszczególne światopoglądy religijne i świeckie (por. Tillich 1987, rozdz. IV - Typy wiary). Reinterpretacja pojęcia wiary może skutkować inkluzywistycznym praktycznie podejściem do edukacji religijnej, niewykluczającym żadnej osoby w jej realizacji.

2. Tillich twierdzi, że zarówno podmiot, jak i przedmiot wiary winny być uchwycone w ich ostateczności. Przekonanie o ostateczności wiary podmiotu i przedmiotu, będąca składową antropologiczną, a nie eklezjalną, prowadzi do wniosku, że nikomu nie powinno się odmówić chęci ostatecznego spełnienia, nawet jeśli tej ostateczności nie będzie szukał w światopoglądach metafizycznych, utrzymujących, że ostateczność podmiotu i przedmiotu wiary spełnia się jedynie przy założeniu realności transcendencji. Świecko nastawione jednostki nie powinny być więc wykluczone z edukacji religijnej, gdyż ostateczności nie wolno automatycznie łączyć z bytami metafizycznymi, jakkolwiek rozumianymi. Daje się przecież teoretycznie owa ostateczność także wyrażać w światopoglądach immanentnych, nie wykraczających poza doczesność (por. Humeniuk 2017). 
3. Tillich utrzymuje, że wiara jako troska ostateczna wyraża się w symbolach wiary, „bo tylko język symboliczny potrafi wyrazić to, co ostateczne” (Tillich 1987, rozdz. 3: Symbole wiary). Nawet gdyby cała ludzkość w procesie rozwoju przyjęła takie same symbole wiary, to uniwersalność tych symboli nie będzie dowodzić ich ostateczności. Wciąż pozostaną warunkowe i nieostateczne w swej naturze. Ekskluzywistycznie uprawiana edukacja religijna narażona jest na niebezpieczeństwo absolutyzacji poszczególnych symboli wiary i zacierania w świadomości wyznawców ich językowej symboliczności. Inkluzywistycznie realizowana edukacja religijna $z$ definicji będzie musiała podkreślać niedosłowność symboli, a także dopuszczać ich nieostateczność i różnorodność. Inkluzywizm edukacji religijnej wyraźnie koreluje z nieostatecznością i niedosłownością symboli religijnych.

4. Chociaż podmiot wiary ma w sobie perspektywę ostateczności, to jednak sam w sobie jest nieostateczny, tak jak nieostateczne są i same symbole wiary. Nieostateczność podmiotu wiary skutkuje towarzyszącym i nieodzownym wierze zwątpieniom oraz błądzeniom. Inkuzywistycznie realizowana edukacja religijna naturalnie uwydatnia nieostateczność sformułowań dogmatycznych artykułowanych przez podmioty wiary i wskazuje na inherentny im wymiar zwątpienia. Przy inkluzywistycznej praktyce edukacji religijnej niemożliwość ostatecznego rozstrzygnięcia, które z prezentowanych rozstrzygnięć światopoglądowych jest właściwe, konsekwentnie prowadzi do postaw uwzględniających wątpienie podmiotu wiary i niedoskonałość artykulacji przedmiotu wiary.

\section{Troska ostateczna w XXI wieku}

W zakończeniu chciejmy zwrócić uwagę na fakt, że Dynamika wiary powstaje na początku drugiej połowy XX wieku (1957). Jej kontekst stanowią zatem ideologie narodowego socjalizmu oraz komunizmu, skutkujące kultem przywódcy i totalitarną władzą partii politycznych (NSDAP, KPZR). Strategia argumentacyjna Tillicha dąży do przekroczenia immanentnych absolutyzmów i ukierunkowuje na poszukiwania ostatecznego spełnienia w rzeczywistości przekraczającej doczesność. Odpowiedzią ma być światopogląd chrześcijański, odpowiednio zreinterpretowany przez Tillicha. Autor zdaje się wciąż jednak myśleć na sposób absolutystyczny, wprowadzając kategorię wiary jako ostatecznej troski podmiotu wiary. Według niego owa troska ostateczna ma występować u każdego człowieka. Każdy w końcu czegoś się w swym zatroskaniu chwyta. Chodzi tylko o to, żeby przedmiot tego zatroskania nie okazał się uwarunkowany, a więc niedający ostatecznego spełnienia (kult jednostki, narodu etc.). Przy takim ujęciu Tillich odrzuca ateizm, rozumiany jako brak ostatecznego zatroskania.

Pojawia się w tym miejscu wątpliwość, która może mieć przełożenie na edukację religijną. Otóż ponad 60 lat po ukazaniu się książki Tillicha daje się dostrzec 
w mentalności europejskiej tendencje polegające na odrzucaniu chęci uchwycenia się czegokolwiek na sposób ostateczny. Można powiedzieć, że ta tendencja nie jest udziałem jedynie ateistycznej czy agnostycznej części społeczności europejskiej, ale także środowisk odwołujących się do tradycji chrześcijańskiej. Nie tylko w osobach niewierzących, ale i wierzących obecny jest sceptycyzm wobec unifikującej narracji światopoglądowej. Wśród większości chrześcijan wiara w Boga, jako ostatecznego przedmiotu troski ostatecznej, zdaje się przekształcać w jedną tylko ze sfer funkcjonowania człowieka, niekoniecznie determinującą wszystkie pozostałe. Wiara chrześcijańska w społeczeństwie zachodnim to obecnie jedna z dziedzin życia społecznego, nieroszcząca już sobie praw do nadrzędności. Straciła ona status ostateczności. Stąd może rodzić się pytanie o to, czy Tillichowska wiara, rozumiana jako troska ostateczna, nie mogłaby przestać być traktowana jako uniwersalna przypadłość ludzka. Tym samym w praktycznej edukacji religijnej nie powinno się raczej zakładać, że jednostka aksjomatycznie ma potrzebę jednego ostatecznego spełnienia, i należy dopuścić takie modele, w których nie występuje jeden nieuwarunkowanie zdefiniowany przedmiot zatroskania (wiary).

\section{Inkluzywistyczny przedmiot troski ostatecznej}

Inne zastrzeżenie, które warto poczynić w zdominowanej myśleniem teistycznym kulturze polskiej, dotyczy natury przedmiotu, będącego obiektem ostatecznego zatroskania człowieka. Edukacja religijna musi bowiem uwzględniać pluralizm świadomości religijnej (Milerski 1998b, s. 218-240). Dla przykładu, czy zdobywająca coraz większą popularność na Zachodzie filozofia i duchowość buddyjska (Chat 2002, s. 20-24) dają się wpisać w model myślenia na sposób absolutystyczny, proponowany przez Tillicha? (por. Tillich 1963, rozdz. 3). Założenia teoretyczne buddyzmu zdają się bowiem podważać zarówno realność podmiotu i przedmiotu wiary, jak też ich ostatecznej natury (por. Lorek 2017). Warto podkreślić, że Tillich nie pojmuje przedmiotu troski ostatecznej jako bytu. W książce Moje poszukiwania absolutów podsumowuje część swoich rozmyślań: „w analitycznym opisie pokazaliśmy obecność absolutów we wszechświecie relatywności i wskazaliśmy na postawę wszystkiego, co absolutne - na sam Absolut. Metoda, według której postępowaliśmy, uwolniła nas od myślenia w ramach pytań i argumentów dotyczących istnienia Bytu absolutnego, niezależnie od tego, czy nazwiemy go «Bogiem», Jednym, Brahman-Atmanem, Losem, Naturą czy Życiem. To, do czego doprowadziły nas nasze analizy, Absolut sam, nie jest bytem absolutnym, co stanowi contradictio in terminis. Jest Samym Byciem" (Tillich 2017, s. 97). Trzy strony wcześniej Tillich pisze podobnie: „Odkryliśmy, że wszystkie absoluty wskazują na coś poza nimi, na najbardziej podstawowy absolut ze wszystkich, na bycie samo poza rozbiciem na przedmiot i podmiot" (Tillich 2017, s. 94).

Tillich jest więc przekonany o obecności absolutu we wszystkich religiach: „Religijny absolut jest najwyraźniej wyrażony w Wielkim Przykazaniu: „Będziesz 
miłował Pana Boga swego całym sercem, całą swoją duszą i całym swoim umysłem” (za Biblią Tysiąclecia, Mt 22, 37); tym jest absolutność w języku religijnym i stanowi to bazę mojej definicji religii jako „stanu bycia pochwyconym przez ostateczną troskę". Wielkie Przykazanie jest żydowskie i chrześcijańskie, ale podobne wyrażenia absolutności obecne są we wszystkich religiach" (Tillich 2017, s. 98). Tillich więc nie rozumie przedmiotu troski ostatecznej jako bytu i jest przekonany o możliwości jego doświadczenia także w religiach nieteistycznych.

Co więcej, Tillich (2017, s. 102) twierdzi, że doświadczenie Absolutu, tego, co ostateczne, występuje także poza religiami: „Ostateczne w bycie i znaczeniu nie może być ograniczone, nie może zostać uchwycone przez jakąkolwiek konkretną religię, w jakimkolwiek świętym miejscu czy przez jakąkolwiek uświęconą czynność". To, co ostateczne, jest do uchwycenia w tym, co niereligijne, i co znajduje się poza religią, chociaż nie bezpośrednio, gdyż nie jest symbolizowane (Tillich 2017, s. 101). Stąd też, konkluduje Tillich (2017, s. 103): „Sekularyzm otrzymuje w ten sposób, oprócz innych rzeczy, pozytywne religijne znacznie, wbrew powszechnemu potępieniu w kazaniach i kościelnych publikacjach".

Widać więc, że Tillichowska reinterpretacja wiary jako troski ostatecznej przybiera wyraźnie inkluzywistyczne rysy, obejmuje wszystkie religie oraz włącza sferę świecką. Tillich wręcz przestrzega przed utożsamieniem konkretnej religii z samym Absolutem. Prowadzi to do wojen religijnych, gdy „partykularną manifestację świętości utożsami się z samą świętością" (Tillich 2017, s. 104; szerzej: s. 108-114).

W podsumowaniu niech znów wybrzmi sam Tillich (2017, s. 113): „W naszych dia$\operatorname{logach} \mathrm{z}$ innymi religiami nie powinniśmy nikogo nawracać. Zamiast tego musimy starać się doprowadzić inne religie do ich własnych głębi, do tego punktu, w którym zrozumieją, że są świadkami Absolutu, ale same nim nie są”. Taki postulat wydaje się stać przed edukacją religijną współczesności. Reinterpretacja chrześcijańskiego pojęcia wiary zaproponowana przez Tillicha zaprasza do dostrzeżenia w każdej religii i w świeckich sferach życia człowieka głębi Absolutu. Jednocześnie przestrzega przed utożsamianiem jakiejkolwiek religii z nim samym. Z tej perspektywy Absolut jako przedmiot troski ostatecznej mógłby być inkluzywistycznie ujęty, bez względu na konkretne symbole wiary wyznawane przez danego człowieka.

\section{Bibliografia}

Chat E. (2002). Dialog chrześcijańsko-buddyjski po Soborze Watykańskim II. „Kieleckie Studia Teologiczne”, nr 1/2, s. 7-24.

Humeniuk M. (2017). Między skończonościa i nieskończonościa - religijność a doświadczanie świata życia. W: Humeniuk M., Paszenda I. (red.). Codzienność jako wyzwanie edukacyjne. Wrocław: Instytut Pedagogiki Uniwersytetu Wrocławskiego.

Lorek P. (2017). Interbyt, uważność i takość - mistrz zen, Thich Nhat Hanh, cytuje Biblię. „Wrocławski Przegląd Teologiczny”, nr 25/1, s. 179-194. 
Matuszyk M. (2015). Paul Tillich. W: Finzsch N., Ruchniewicz K., Kurpiel A. (red.). Skreśleni. Odbieranie tytułów naukowych na Friedrich-Wilhelms-Universietät zu Breslau w latach 1933-1945. Wrocław: Oficyna Wydawnicza ATUT - Wrocławskie Wydawnictwo Oświatowe.

Mech K. (1997). Chrześcijaństwo i dialektyka w koncepcji Paula Tillicha. Kraków: Zakład Wydawniczy „Nomos”.

Mech K. (1999). Wiara budująca sens. W kręgu badań nad konstytucją specyficznie religijnego sensu. W: Mech K. (red.). Człowiek wobec religii. Filozoficzne aspekty religijnego sensu. Kraków: Zakład Wydawniczy „Nomos”.

Milerski B. (1998a). Religia a szkoła. Status edukacji religijnej w szkole w ujęciu ewangelickim. Warszawa: Chrześcijańska Akademia Teologiczna.

Milerski B. (1998b). Religia w społeczeństwie pluralistycznym. W: Milerski B. (red.). Elementy pedagogiki religijnej. Warszawa: Chrześcijańska Akademia Teologiczna.

Patalon M. (2007). Pedagogika ekumenizmu. Procesualność jako paradygmat interkonfesyjnej i interreligijnej hermeneutyki w ujęciu Johna B. Cobba, Jr. Gdańsk: Wydawnictwo Uniwersytetu Gdańskiego.

Tillich P. (1963). Christianity and the Encounter of the World Religions. New York: Columbia University Press.

Tillich P. (1987). Dynamika wiary. Szostkiewicz A. (tłum.). Poznań: Wydawnictwo „W drodze”.

Tillich P. (1994). Pytanie o Nieuwarunkowane. Pisma z filozofii religii. Zychowicz J. (tłum.). Kraków: Wydawnictwo Znak.

Tillich P. (2017). Moje poszukiwania absolutów. Leszczyński M. (tłum.). Łódź: Wydawnictwo Uniwersytetu Łódzkiego.

\title{
THE INCLUSIVISTIC REINTERPRETATION OF THE NOTION OF FAITH BY PAUL TILLICH AND ITS IMPLICATIONS FOR THE PRACTICE OF RELIGIOUS EDUCATION
}

\begin{abstract}
Paul Tillich reinterprets the Christian notion of faith in God as a being and presents it as the ultimate concern. Faith thus becomes a central and necessary state for everything. Although the subject of faith is finite, it has the ability to strive for the ultimate, infinite object. The object of faith can only be expressed symbolically, thus there is not just one true symbol of faith. The finite nature of an object inevitably gives rise to doubt and wandering. Such an understanding of faith has implications for religious education that should become inclusive, bringing in all human beings, both religious and nonreligious, helping them to deepen their faith on their own terms as well as warning them against the danger of absolutization of their own particular symbols of faith. Especially theistic religions need to remember that the ultimate object of faith goes beyond the absolute being.
\end{abstract}


The ultimate concern is also present in secular, as well as religious experience, although not expressed directly.

Keywords: Tillich; ultimate concern; faith; religious education; inclusivism.

Piotr Lorek - doktor habilitowany, prof. EWST, biblista i teolog ewangelicki, dziekan Ewangelikalnej Wyższej Szkoły Teologicznej we Wrocławiu. Adres korespondencyjny: Ewangelikalna Wyższa Szkoła Teologiczna we Wrocławiu, ul. św. Jadwigi 12, 50-266 Wrocław. Adres e-mailowy: p.lorek@ewst.pl. 